\title{
Safety of Beauveria bassiana (Bals.) Vuill. to Gallus domesticus $\mathbf{L}$.
}

\author{
Jucelaine Haas-Costa ${ }^{1}$, Luis Francisco Angeli Alves ${ }^{1,2^{*}}$ and Alaxsandra Aparecida Daros ${ }^{2}$ \\ ${ }^{I}$ Programa de Pós-Graduação em Agronomia; Universidade Estadual do Oeste do Paraná. ${ }^{2}$ Laboratório de \\ Biotecnologia Agrícola; Universidade Estadual do Oeste do Paraná; C. P.: 711; 85819-110; Cascavel - PR - Brasil
}

\begin{abstract}
Beauveria bassiana, an important insect pathogen was used to evaluate its effect on the feeding, behavior, histology of the digestory system and anatomy of Gallus domesticus. The fungus (strain Unioeste 4) was administrated orally treated with chicken food. Chicken feces were collected, and the birds observed for 28 days. Also, were evaluated the weight of the birds, as well as any sign of intoxication or pathological modification. Tissue samples were withdrawn to test lesions with the optic microscope. There was $100 \%$ of survival of the birds, and no behavior alteration or external lesion was found. The test group presented the highest weight gain (1383.9 $\pm 54.4 \mathrm{~g})$. Viable conidia were observed in the feces until $24 \mathrm{~h}$ after feeding the fungus, indicating that there was no germination inside the digestory system. No tissue lesion was observed, providing overwhelming evidence for the safety of B. bassiana to non-target organism $\mathrm{G}$. domesticus.
\end{abstract}

Key words: biological control, microbial control, non-target organisms, birds

\section{INTRODUCTION}

The development of resistance by many important insect pests, the continuous increase in of chemicals price used for the pest control, along with the concern about the environment protection has encouraged studies and use of biological control (Laird et al., 1990; Slinninger et al., 2003). One of the most important entomopathogenic fungi used as biocontrol agents is Beauveria bassiana Bals. Vuill. (Deuteromycota: Hyphomycetes), which is able to cause high levels of mortality in Coleoptera, Lepidoptera, Hemiptera, Diptera, Hymenoptera and Orthoptera (Alves, 1998). Although there is increasing interest in the use of this and other microbial control agents, there is little knowledge about not only its effect on the environment, but also on other control agents and non-target organisms, especially vertebrates (Jonsson and Maia, 1999; Alves, 1998). Due to these facts, organisms believed as safe should be tested in all possible conditions in which they could cause any harm (Laird et al., 1990).

As information about the safety of B. bassiana to vertebrates is relative scarce and the results are conflictive (Ignoffo, 1973; Burges, 1981; LAIRD et al., 1990; Genthner and Middaugh, 1992; 1995; Middaugh and Genthner, 1994; Genthner et al., 1995; Jonsson and Genthner, 1997; Alves, et al., 2008). Several authors have emphasized the need of conducting additional tests (Ignoffo, 1973; Burges, 1981; Parker et al., 1997; Brimner and Bolland, 2003). However, Zimmermann (2007 a,b)

*Author for correspondence: lfaalves@ unioeste.br 
published an extensive review about the effects of B. bassiana and Metarhizium anisopliae fungi on vertebrates.

The Ministério da Agricultura, Pecuária e Abastecimento (MAPA) also establishes procedures to study the efficacy of biopesticides and their possible action upon non-target organisms (Mapa, 2006). Nardo et al. (1999) suggested the use of chicken to test aiming to evaluate the effect of entomopathogenic fungi to bird as non-target organism.

Gallus domesticus is a cosmopolitan and easybreeding bird, besides of being a non-target organism of $B$. bassiana in the field and poultry houses where this fungus occurs epizootically or its applied to control of the lesser mealworm Alphitobius diaperinus (Coleoptera, Tenebrionidae) (Panzer, 1979) in poultry houses (Steinkraus et al. 1991; Geden and Steinkraus, 2003; Alves et al. 2004; Rohde et al., 2006; Alves et al., 2005). Therefore, this work aimed to evaluate the effect of $B$. bassiana upon the feeding, behavior, histology of the digestory system and anatomy of G. domesticus.

\section{MATERIAL AND METHODS}

The methodology used was based upon the "Protocolo de avaliação de agentes microbianos de controle de pragas para registro como bioinseticidas" (Nardo et al., 1999), when regarding to the birds. The fungus used was Beauveria bassiana, strain UNIOESTE 4, obtained from the lesser mealworm cadavers (Alphitobius diaperinus Panzer) from poultry houses in Cascavel, PR. This strain was chosen because has great potential for the control of A. diaperinus (Panzer) in poultry houses (Rohde et al., 2006). The entomopathogen was multiplied, from the original inoculum, stored as pure conidia in freezer $\left(-10^{\circ} \mathrm{C}\right)$, onto Petri dishes containing culture medium (PDA) with tetracycline and incubated in an incubator $\left(26^{\circ} \mathrm{C}, 14 \mathrm{~h}\right.$ photophase) for seven days. From these dishes was then inoculated fungal onto plastic bags containing pre-cooked rice, which were incubated from seven to ten days on the same conditions as Alves and Pereira (1989). The fungus was separated from the rice and the conidia were stored in plastic bags in freezer $\left(-10^{\circ} \mathrm{C}\right)$ for 10 days, until the beginning of the test.
The fungus viability was evaluated before the experiment. In order to inactivate the fungus, it was autoclaved at $121^{\circ} \mathrm{C}$ for 20 minutes at $1 \mathrm{~atm}$.

The organisms used in the test were male chickens (Gallus domesticus), with 11 days old, provided by Diplomata Industrial e Comercial Ltda. from Cascavel, PR. The birds were maintained at 20 to $30^{\circ} \mathrm{C}$ and $16 \mathrm{~h}$ photophase for three days until the experiment installation. The animals were fed $a d$ libitum with commercial chicken food composed by corn, soybean and sugarcane meal and amino acids and without antibiotics, to avoid interference in the fungus viability.

\section{Fungus and birds evaluation}

The birds were separated into three groups, maintained in $0.80 \mathrm{~m}^{2}$ cage $(1.0 \times 0.80 \times 1.0 \mathrm{~m}-$ $\mathrm{L}: \mathrm{W}: \mathrm{H})$, being the top movable so that the maintenance of the birds were easier during the test. Each group was composed by 10 birds identified with colorful rings around their inferior limbs. The groups were: (1) Active fungus: birds fed with diets containing B. bassiana $\left(10^{9}\right.$ conidia/g chicken food); (2) Inactive fungus: fed with inactivated fungus at the same concentration and (3) Control: birds fed just with the diet, but also left in the same conditions as the formers. Daily, for five days, the birds were fed with diet containing fungus, being previously maintained in fast for $15 \mathrm{~h}$. The fungus was mixed to the chicken food immediately before the administration to the birds. After the treatment period, the birds were fed ad libitum with the commercial ration without antibiotics.

\section{Feces evaluation}

Samples of the test group feces were collected daily, at the same daytime, from the $1^{\text {st }}$ to the $9^{\text {th }}$ day of experiment in order to verify the presence/absence of fungus after the passage through the animals' gastrointestinal tract. Suspensions with $1 \mathrm{~g}$ of feces $+9 \mathrm{~mL}$ of distilled water + Tween $80^{\circledR} 0.1 \%$ were prepared, and $0.1 \mathrm{~mL}$ was inoculated onto the selective media for the fungus isolation. These dishes were incubated at $26^{\circ} \mathrm{C}$ and $14 \mathrm{~h}$ photophase for 7 days (Alves et al., 1998).

\section{Birds evaluation}

The birds were observed for 28 days, for any clinical signs of any effects associated with the treatment. These included: uncommon vocalization, change in gait or coordination, 
anorexia, ruffled or denuding of feathers, weakness or decreased responsiveness to investigator presence. Any evidence of gastrointestinal disorder (vomition or diarrhea) (Johnson et al., 2002) or skin lesions were verified. The birds' weight was measured before the fungus administration and on the days 0, 7, 14 and 28 days after the ingestion (DAI).

All the birds were sacrificed at the end of the evaluation period (28 DAI), and three birds from each group were selected at random and necropsied in order to observe internal pathological alterations. Samples from the lungs, heart, small intestine, kidney and liver were collected. These tissues were fixed in $70 \%$ alcohol and embedded in paraffin blocks, sectioned at 7 $\mu \mathrm{m}$ and stained with HE (Hematoxilin and Eosin), following techniques from Ganter and Jolles (1970) and Behmer et al. (1976) to verify possible lesions caused by the fungus, as alterations to normal cellular structure, inflammation or necrosis of the tissue (Johnson et al., 2002). The experimental design was completely randomized with three treatments (control, active fungus and inactive fungus) and ten replications. The results of the weight gain of the birds were evaluated using the $\mathrm{F}$ ratio and means compared with Tukey test $(\mathrm{P}<0.05)$. A split-plot arrangement was used to evaluate the weight of the birds.

\section{RESULTS AND DISCUSSION}

\section{Bird evaluation}

All of the birds survived during the experiment and no kind of external lesions was found. Histological examination of the tissues (lungs, heart, small intestine, kidney and liver) revealed no consistent changes associated with any treatment, showing no kind of visible alterations. Similar observation was reported in tested ducks exposed to injection of concentrated suspension of Lagenidium giganteum by intraperitonial route. Also, Rezende (2009) no observed significatively alterations on Gallus domesticus after oral inoculation of B. bassiana suspension. Otherwise, when feeding the birds with the fungus there was one death which was not attributing to the fungus administration (Kerwin et al. 1988, 1990). The same fungus was administrated by Burges (1971) to rats by tracheal instillation causing $67 \%$ of mortality. This high mortality percentage was due to the obstruction of the airway or inflammatory reaction due to the huge amount of strange material.

Relating to the birds behavior, all the individuals presented the same pattern with no deviations from the normal (Table 1). Similar results were found by Johnson et al. (2002) when feeding kestrels (Falco tinnunculus L.) with grasshoppers infected by B. bassiana and Metarhizium anisopliae, and by Althouse (1997), cited by Johnson (2002), testing B. bassiana in Phasianus colchicus. As noted by Laird (1990), these entomopathogens are specific, which reduce the risk of infection of species in different taxonomic classes from the target species. Pereira et al. (1998) asserted that it happens due to the great difference between the physiology of the organisms, as the body temperature of the birds $\left(40^{\circ} \mathrm{C}\right)$, much higher than the insects' organism. Besides, the homoeothermic immune system is complex and efficient, hindering fungi growth. Inglis et al. (1999) claimed that this fungus was very sensitive to variable temperatures, and Alexandre et al. (2006) verified that at $32^{\circ} \mathrm{C}$, the germination of $B$. bassiana was totally inhibited.

Table 1 - Survival and behavior evaluation of Gallus domesticus submitted to feeding of Beauveria bassiana in 3 treatments: active fungus, inactive fungus and control, during 4 weeks (Temperature: $25 \pm 5^{\circ} \mathrm{C}$; photophase: 14 hours).

\begin{tabular}{lcccc}
\hline & \multicolumn{4}{c}{ Observed response } \\
\cline { 2 - 5 } \multicolumn{1}{c}{ Treatments } & $\begin{array}{c}\text { Individuals per } \\
\text { treatment (n) }\end{array}$ & $\begin{array}{c}\text { Behaviour } \\
\text { alteration }\end{array}$ & Dead individuals & Survival (\%) \\
\hline Control & 9 & Negative & 0 & $100 \mathrm{a}$ \\
Inactive fungi & 10 & Negative & 0 & $100 \mathrm{a}$ \\
Active fungi & 10 & Negative & 0 & $100 \mathrm{a}$ \\
\hline
\end{tabular}




\section{Birds' weight}

There was no interaction between $B$. bassiana and the time of evaluation on the birds' weight (Table $2)$. Besides, there was no statistical difference between, the values of beginning ( 0 time) and two following weeks among the three groups. But on the last evaluation, the birds treated with active fungus showed higher weight $1718.9( \pm 58.46)$, when compared to the other two groups: control $(1610.0 \pm 63.31)$ and treated with inactive fungus, $(1603.3 \pm 47.05)$. The same was observed about the mean weight gain.

Table 2 - Mean weight gain (g) of Gallus domesticus in 3 treatments: active fungus, inactive fungus and control group on week $0,1,2,3$ and 4 of evaluation, as well as mean of total weight gain (g) (temperature: $25 \pm 5^{\circ} \mathrm{C}$; photophase: 14 hours).

\begin{tabular}{ccccccc}
\hline \multirow{2}{*}{ Treatment } & \multicolumn{5}{c}{ Weeks } & Mean weight \\
\cline { 2 - 7 } gain
\end{tabular}

CV treatment $(\%)=12,24 \quad$ CV time $(\%)=11,37 \quad$ CV weight gain $(\%)=12,39$

Means $( \pm$ SE) followed by the same capital letter in columns and minuscule letter in lines are not different from each other by the Tukey test at $5 \%$ significance.

In all the treatments, there was an exponential increase of weight starting from the second week of evaluation, until the last weighing (Fig. 1), indicating that there was no physiological alteration caused directly by the intact or digested conidia, mycelium or by their toxins, which could lead to the reduction or to the non gain of weight. According to Gonzáles and Sartori (2002), a fast increase of the body mass of the chicken in the beginning of the development takes place which diminishes as time passes by, until it reaches full development. Rezende (2009), testing the effect of oral administration of $B$. bassiana in broiler chickens, also found no statistical significatively difference in weight gain. Johnson et al. (2002) did not find evidence that the consumption of infected grasshoppers with $M$. anisopliae and B. bassiana by male pheasants ( $P$. colchicus) had affected the weight gain of the birds.

Presence of $B$. bassiana in $G$. domesticus feces The conidia of $B$. bassiana were viable between the $1^{\text {st }}$ and the $6^{\text {th }}$ day, indicating that those went through the gastrointestinal tract rapidly, staying for not more than $24 \mathrm{~h}$ (Table 3). This fact associated with the different $\mathrm{pH}$ through the gastrointestinal tract and the high temperature of the body of the birds $\left(40^{\circ} \mathrm{C}\right)$ is believed to have prevented the conidia to germinate and cause infection or release any kind of toxins in the birds' body. These results were according to Alves (1998), who found that fungi only germinated when they found favorable conditions of humidity, temperature, $\mathrm{pH}$, oxygen and nutrition, which corroborate with the results found in this study. Furlan and Macari (2002) related that in both chickens and turkeys, when markers were used to the food, these were found in the feces around three hours after the ingestion, and after $24 \mathrm{~h}$ all markers were recovered.

However, Smits et al. (1999) disagreed with these results, mentioning that they did not observe $M$. flavoridae conidia in the feces of pheasants treated with this fungus in its food. Johnson et al. (2002), evaluating the same species ( $P$. colchicus), were not able to find other fungi than Mucor and Penicillium when analyzing feces and blood of the birds fed with $B$. bassiana and $M$. anisopliae. Although, the authors explained that, appraising samples of the birds' diet, a small number of viable conidia were found. Thus, they concluded that the absence of B. bassiana and M. anisopliae in the birds' body fluids was not conclusive.

The data presented here led to the conclusion that B. bassiana was present and viable in the birds feces until $24 \mathrm{~h}$ after the ingestion, indicating that 
it did not germinate in the birds body. In addition, there was no negative effect upon the birds gain weight. Also, there was no bird mortality due to the fungus ingestion, nor there was any sign of behavior alteration, external or tissue lesion in the evaluated organs. Thus, it could be concluded that B. bassiana did not cause harm on G. domesticus, being secure for this non-target organism.
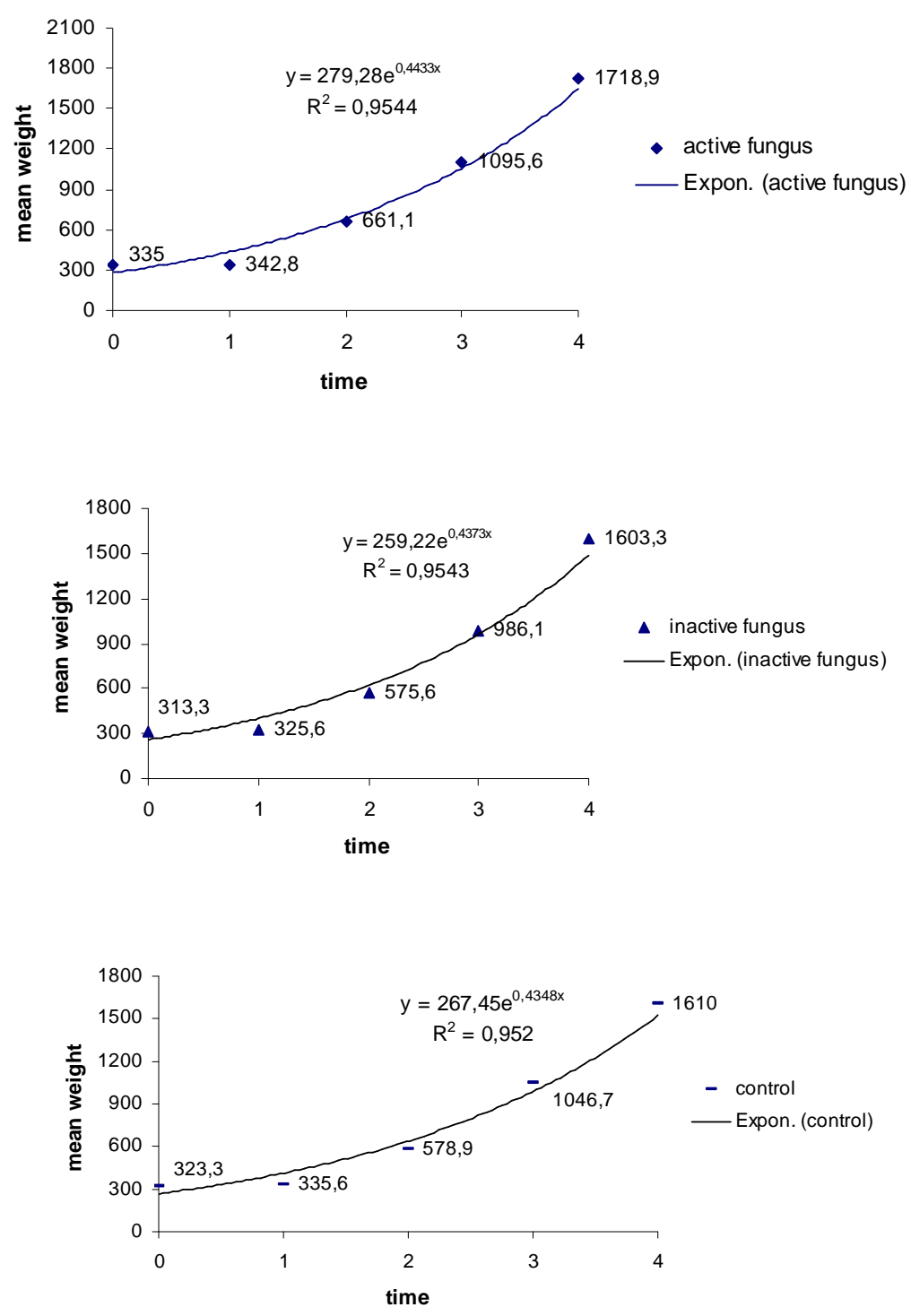

Figure 1 - Weight gain (g) in Gallus domesticus in three treatments: active fungus, inactive fungus and control on 4 weeks of evaluation (temperature: $25 \pm 5^{\circ} \mathrm{C}$; photophase: 14 hours).

Table 3 - Presence of viable Beauveria bassiana conidia in Gallus domesticus feces treated with active B. bassiana during the first 9 days of evaluation $\left(25 \pm 5^{\circ} \mathrm{C}\right.$; Photophase: 14 hours $)$.

\begin{tabular}{llllllllll}
\hline \multicolumn{10}{c}{ Days of evaluation } \\
\hline & $\mathbf{1}$ & $\mathbf{2}$ & $\mathbf{3}$ & $\mathbf{4}$ & $\mathbf{5}$ & $\mathbf{6}$ & $\mathbf{7}$ & $\mathbf{8}$ & $\mathbf{9}$ \\
\hline Presence/ Absence & + & + & + & + & + & + & - & - & - \\
\hline
\end{tabular}

$+=$ presence of conidia in Gallus domesticus feces; - = absence of conidia in Gallus domesticus feces. 


\section{RESUMO}

Beauveria bassiana é um importe entomopatógeno, sendo avaliado seu efeito sobre a alimentação, comportamento e histologia do sistema digestório de Gallus domesticus. O fungo (isolado Unioeste 4) foi administrado oralmente às aves, misturado à ração. Estas foram observadas por 28 dias e as fezes coletadas diariamente para análise. Também foi avaliado o peso das aves, bem como sinais de intoxicação ou modificação patológica. Amostras teciduais foram retiradas para verificar lesões com o microscópico óptico. Houve sobrevivência de $100 \%$ das aves avaliadas e nenhuma alteração comportamental ou lesão externa durante o experimento. $\mathrm{O}$ grupo teste apresentou o maior ganho de peso $(1383,9 \pm 54,4 \mathrm{~g})$, sendo mais acentuado a partir da segunda semana. Observou-se a presença de conídios viáveis nas fezes somente até 24 horas após a ingestão do fungo, indicando que não houve germinação nas aves. Nenhuma lesão tecidual foi verificada, de forma que $B$. bassiana mostrou-se seguro para o organismo não-alvo $G$. domesticus.

\section{REFERENCES}

Alexandre, T.M.; Alves, L.F.A.; Neves, P.M.O.J. and ALVES, S.B. (2006), Efeito da temperatura e cama do aviário na virulência de Beauveria bassiana (Bals.) Vuill. E, Metarhizium anisopliae (Metsch.) para o controle do cascudinho (Alphitobius diaperinus) (Panzer) (Coleoptera: Tenebrionidae). Neotrop. Entomol., 35, 75-82.

Alves, L.F.A.; Alves, V.S.; Bressan, D.F.; Neves, P.M.O.J. and Alves, S.B. (2004), Ocorrência de Metarhizium anisopliae (Metsch.) Sorok. em Adultos de Cascudinho (Alphitobius diaperinus) (Panzer) (Coleoptera: Tenebrionidae) em Aviários Comerciais em Cascavel, PR. Neotrop. Entomol., 33, 793-795

Alves, S.B. (1998), Fungos Entomopatogênicos. In. Controle microbiano de insetos. 2. ed. Piracicaba: FEALQ, 289-371.

Alves, L.F.A.; Gassen, M.H.; Pinto, F.G.S.; Neves, P.M.O.J. and Alves, S.B. (2004), Ocorrência Natural de Beauveria bassiana (Bals.) Vuilleman (Moniliales: Moniliaceae) Sobre o Cascudinho, Alphitobius diaperinus (Panzer) (Coleoptera: Tenebrionidae), em Aviário Comercial de Cascavel, PR. Neotrop. Entomol., 34, 507-510.
Alves, S.B. and Pereira, R.M. (1989), Produção do Metarhizium anisopliae (Metsch.) Sorok. e Beauveria bassiana (Bals) Vuill. em bandejas. Ecossistema., 14, 188-192.

Behmer, O.A., Tolosa, E.M.C.D. and Freitas Neto, A.G.D. (1976), Manual de técnicas para histologia normal e patológica. São Paulo, Edart/Edusp, 240 p.

Brasil, Ministério da Agricultura, Pecuária e Abastecimento, Instrução Normativa Conjunta no. 3, de 10 de março de 2006., Diário Oficial da União, p. 23-25.

Brimner, T.A. and Boland, G.J. (2003), A review of the non-target effects of fungi used to biologically control plant diseases. Agric. Ecosyst. Environ.Agric., 100, 03-16.

Burges, H.D. 1981. Safety, Safety Testing and Quality Control of Microbial Pesticides. In.__: Microbial control of pests and plant diseases. London, Academic Press Inc. 738-768.

Furlan, R.L. and MACARI, M. (2002), Motilidade Gastrintestinal. In:__ Fisiologia Aviária Aplicada a Frangos de Corte, 2a edição, 375 p.

Ganter, P. and JOLLES, G. (1970), Histochimie normale et pathologique. Paris, Gauthier-Villars, t. 2, $1003 \mathrm{p}$.

Geden, C.J. and Steinkraus, D.C. (2003), Evaluation of Three Formulations of Beauveria bassiana for Control of Lesser Mealworm and Hide Beetle in Georgia Poultry Houses. Vet. Entomol., 96, 16021607.

Genthner, F.J. and Middaugh, D.P. (1992), Effects of Beauveria bassiana on embryos of the inland silverside fish (Menidia beryllina). Appl. and Environ. Microbiol., 58, 2840-2845.

Genthner, F.J. and Middaugh, D.P. (1995), Nontarget testing of an insect control fungus: effects of Metarhizium anisopliae on developing embryos of the inland silverside fish Menidia beryllina. Dis. Aquat. Org., 22, 163-171.

Genthner, F.J.; Middaugh, D.P. and Foss, S.S. (1995), Validation of embryo test for determining effects of fungal pest control agents on nontarget aquatic animals. Arch. Environ. Contam. Toxicol., 29, 540544.

Gonzales, E. and Sartori, J.R. (2002), Crescimento e metabolismo muscular. In:__ Fisiologia Aviária Aplicada a Frangos de Corte, 2 a edição, 375 p.

Ignoffo, C.M. (1973), Effects of entomopathogens on vertebrates. Annals New York Academy of Science, 217, p. 141-164.

Inglis, G.D.; Duke, G.M.; Kawchuk, L.M. and GOETTEL, M.S. (1999), Influence of oscillating temperatures on the competitive infection and colonization of the migratory grasshopper by Beauveria bassiana and Metarhizium flavoviride. Biol. Control, 14, 111-120. 
Johnson, D.L.; Smits, J.E.; Jaronski, E.T. and Weaver, D.K. (2002), Assessment of health and growth of ring-necked pheasants following consumption of infected insects or conidia of entomopathogenic fungi, Metarhizium anisopliae var. acridum and Beauveria bassiana, from Madagascar and North America. J. Toxicol. Environ. Health Part A, 65, 2145-2162.

Jonsson, C.M. and Genthner, F.J. (1997), Avaliação do potencial de patogeniciddade e toxicidade do fungo entomopatógeno Colletotrichum gloesporioides isolado de Orthezia em duas espécies de crustáceo, Bol. Pesq. 1, Jaguariúna: Embrapa, 27p.

Jonsson, C.M. and Maia, A.H. (1999), Protocolo de avaliação de agentes microbianos de controle de pragas para registro como biopesticidas. III. Testes em organismos não-alvo do ambiente aquático: organismos zooplanctônicos, organismos fitoplanctônicos e vertebrados. Jaguariúna, Embrapa, $33 \mathrm{p}$.

Kerwin, J.L.; Dritz, D.A. and Washino, R.K. (1988), Confirmation of the safety of Lagenidium giganteum (Oomycetes: Lagenidiales) to mammals. J. Econ. Entomol., 81, 158-171.

Kerwin, J. .; Dritz, D.A. and Washino, R.K. (1990), Nonmammalian safety tests for Lagenidium giganteum (Oomycetes: Lagenidiales), J. Econ. Entomol., 83, 374-376.

Laird, M.; Lacey, L.A. and Davidson, E.W. (1990), Safety of microbial insecticides. Boca Raton, Florida, CRC Press, 259p.

Middaugh, D.P. and Genthner, F.J. (1994), Infectivity and teratogenicity of Beauveria bassiana in Menidia beryllina embryos. Arch. Environ. Contam. Toxicol., 27, 95-102.

Nardo, E.A.B.; SÁ, L.A.N.; Capalbo, D.M.F.; Moraes, G.J.; Oliveira, M.C.B.; Castro, V.L.S.S. and Watanabe, M.A. (1999), Avaliação de Agentes Microbianos de controle de Pragas para Registro como Biopesticidas. São Paulo: Embrapa, 67p.

Parker, B.L.; Skinner, M.; Gouli, V. and Brownbridge, M. (1997), Impact of Soil Applications of Beauveria bassiana and Mariannaea sp. on Non-target Forest Arthropods. Biol. Control, 8, 203-206.

Pereira, R. M.; Alves, S.B. and Reis, P.R. (1998), Segurança no emprego de entomopatógenos In. Controle Microbiano de Insetos, 2. ed. Vol.4 Piracicaba: FEALQ, p.171-193.
Rezende, S.R.F. (2009), Fungos entomopatogênicos no controle do Alphitobius diaperinus (Panzer) (Coleoptera: Tenebrionidae) como estratégia de biosseguridade na avicultura. MsC Thesis, Universidade Federal Rural do Rio de Janeiro, Seropédica, Brasil.

Rohde, C.; Alves, L.F.A.; Neves, P.M.O.J.; Alves, S.B.; Silva, E.R.L. and Almeida, J. E. M. (2006), Seleção de isolados de Beauveria bassiana(Bals.) Vuill. E Metarhizium anisopliae (Metch.) Sorok. contra o cascudinho Alphitobius diaperinus (Panzer) (Coleoptera: Tenebrionidae). Neotrop. Entomol., 35, 231-240.

Slinninger, P.J.; Behle, R.W.; Jackson, M.A. and Schisler, D.A. (2003), Discovery and development of biological agents to control pests. Neotrop. Entomol., 32, 183-195.

Smits, J.E.; Johnson, D.L. and Lomer, C. (1999), Pathological and physiological responses of ringnecked pheasant chicks following dietary exposure to the fungos Metarhizium flavoridae, a biocontrol agent for locusts in Africa. J. Wildl. Dis., 35, 194-203.

Steinkraus, D.C.; Geden, C.J. and Rutz, D.A. (1991), Susceptibility of lesser mealworm (Coleoptera: Tenebrionidae) to Beauveria bassiana: Effects of host stage, formulation, substrate and host passage. $J$. Med. Entomol., 28, 314-321.

Zimmermann, G. (2007a), Review of the entomopathogenic fungi Beauveria bassiana and Beauveria brongniartii. Biocontrol Sci. Technol., 17, 553-596.

Zimmermann, G. (2007b), Review of the entomopathogenic fungus Metarhizium anisopliae. Biocontrol Sci. Technol., 17, 879-920.

Alves, L.F.A.; Alves, S.B.; Oliveira, L.G., Jonsson, C.M. (2008). Efeito do fungo Metarhizium Anisopliae (Metsch.) Sorok. (Deuteromycetes) para Astyanax Scabripinnis (Jenyns, 1842) (Pisces: Characidae). Arq. Inst. Biol., 75, 471-479.

Received: November 19, 2007; Revised: May 21, 2008; Accepted: July 08, 2009. 